Service social

\title{
La revue Service social, d'un directeur à un autre
}

\section{Jacques Vachon}

Volume 38, numéro 2-3, 1989

Les politiques sociales

URI : https://id.erudit.org/iderudit/706434ar

DOI : https://doi.org/10.7202/706434ar

Aller au sommaire du numéro

Éditeur(s)

École de service social de l'Université Laval

ISSN

1708-1734 (numérique)

Découvrir la revue

Citer cet article

Vachon, J. (1989). La revue Service social, d'un directeur à un autre. Service social, 38(2-3), 153-153. https://doi.org/10.7202/706434ar d'utilisation que vous pouvez consulter en ligne.

https://apropos.erudit.org/fr/usagers/politique-dutilisation/ 


\section{La revue Service social, d'un directeur à un autre}

En septembre 1989, Jocelyn Lindsay, en accord avec la direction de l'École de service social, transmettait à Jean-Louis Gendron la responsabilité de diriger la revue Service social.

Au moment de son départ, Jocelyn Lindsay occupait la fonction de directeur depuis cinq ans. Il avait, en effet, succédé à Simone Paré en 1984. Ces années furent marquées par une quantité impressionnante d'innovations, allant de la présentation matérielle de la revue, à une transformation de son mode de gestion, en passant par un réaménagement du contenu scientifique. Ces fécondes innovations permettent aujourd'hui au nouveau directeur non seulement de remplacer l'ancien en toute douceur, mais de prendre en charge une revue dont la qualité et le prestige font l'honneur de l'École de service social de I'Université Laval et des travailleurs sociaux qui y collaborent.

Nous souhaitons donc au nouveau directeur le plus grand des succès et nous remercions très chaleureusement celui qui se retire.

Jacques Vachon, directeur

École de service social 